\title{
FILSAFAT PENDIDIKAN
}

Jenilan*

\section{Abstrak}

Filsafat pendidikan adalah filsafat yang memandang pendidikan sebagai proses memanusiakan peserta didik sehingga mampu berkembang dan beraktualisasi diri dengan segenap potensi asli yang ada dalam dirinya. Ilmu pengetahuan berkembang dari rasa ingin tahu, yang merupakan ciri khas manusia. Ilmu pengetahuan merupakan upaya khusus manusia untuk menyingkapkan realitas, supaya memungkinkan manusia berkomunikasi satu sama lain, membangun dialog dengan mengakui yang lain, dan meningkatkan harkat kemanusiaannya.

Kata Kunci : Filsafat pendidikan, ilmu pengetahuan.

\section{Pendahuluan}

Proses pendidikan adalah proses perkembangan yang bertujuan. Tujuan proses perkembangan itu secara alamiah adalah kedewasaan, sebab potensi manusia yang paling alamiah adalah bertumbuh menuju tingkat kedewanaan, kematangan. Potensi ini akan dapat terwujud apabila prakondisi almiah dan sosial manusia bersangkutan memungkinkan untuk perkembangan tersebut, misalnya iklim, makanan, kesehatan, dan keamanan, relatif sesuai dengan kebutuhan manusia.

Filsafat bertumpu pada kemampuannalaratau rasio manusia, Kebenaran hakiki yang dicari adalah sejauh yang dapat dijangkau oleh akal manusia, Sebagai kegiatan berpikir, filsafat menghasilkan gambaran pemikiran secara menyeluruh dan komprehensif., Pemikiran filsafat bersifat spekulatif, artinya merenung, memikirkan sesuatu sedalam-dalamnya, tanpa keharusan ada kontak langsung degan objek yang dipikirkan.

Aguste Rodin salah seorang pemahat termashur membuat patung Homo Sapiens, manusia yang berfikir. Dimana dalam bayangan Aguste Rodin menggambarkan bahwa manusia senang tiasa berpikir. Setiap saat dari hidupnya, sejak dia lahir sampai masuk liang lahat, dia tak pernah berhenti berpikir. Hampir tak ada masalah yang menyangkut peri kehidupan yang terlepas dari jangkauan pikirannya, dari soal paling remeh sampai soal paling asasi. Berpikir itulah yang mencirikan hakekat manusia dan karena berpikirlah dia menjadi manusia. ${ }^{1}$ 
Ilmu pengetahuan berkembang dari rasa ingin tahu, yang merupakan ciri khas manusia. Ilmu pengethauan merupakan upaya khusus manusia untuk menyingkapkan realitas, supaya memungkinkan manusia berkomunikasi satu sama lain, membangun dialog dengan mengakui yang lain, dan meningkatkan harkat kemanusiaannya. Selanjutnya manusia juga mengalami kebutuhan yang lebih mendalam, yaitu untuk menemukan tata susunan yang sesungguhnya dalam kenyataannya. Berbeda dengan makhluk yang lain yang hubungannya dengan alam bersifat alamiah dan berupa ketundukan mutlak, hubungan manusia dengan alam mengandung unsur ikhtiar, atau upaya untuk hidup secara manusiawi. ${ }^{2}$

ini menunjukkan bahwa dalam berpikir, manusia terlihat dari aspek kemanusiaannya jika dia memikirkan kemajuannya., dan kemajuan kemajuan inilah salah satu isyarat bahwa dalam proses berpikir manusia senangtiasa berupaya berbenah diri untuk hari esok lebih baik dari hari ini, demikian pula pendidikan., pendidikan tidak akan selangkah lebih maju jika hanya diterima apa adanya, namun perlu adanya perbaikan dalam bentuk suatu upaya untuk proses berpikir secara mendalam.
Oleh karenanya dengan memahami filsafat dengan baik maka orang akan dapat mengembangkan secara konsisten ilmu-ilmu pengetahuan yang dipelajari. Filsafat mengkaji dan memikirkan tentang hakikat segala sesuatu secara menyeluruh, sistematis, terpadu, universal dan radikal yang hasilnya menjadi pedoman dan arah dari perkembangan ilmu-ilmu yang bersangkutan. Oleh karenanya yang membantu filsafat pendidikan terlaksanan dengan baik, maka terdapat beberapa teori yang menjadi acuan dalam menopang terselenggaranya pendidikan yang maksimal yaitu:

1. Etika atau teori tentang Nilai

2. Teori ilmu pengetahuan atau Epistimologi dan

3. Teori tentang realitas atau kenyataan dan yang ada dibalik kenyataan yang disebut Metafisika.

4. Permasalahan yaang diidentifikasikan dalam ketiga disiplin ilmu ini menjadi materi yang dibahas di dalam filsafat pendidikan. ${ }^{3}$

Masyarakat zaman modern saat ini telah meyakini tentang eksistensi pendidikan dari yang sifatnya unum sampai kepada yang khusus. Keyakinan ini makin hari diperkuat dengan berkembangnya metode pengukuran dan cara analisa yang dapat dipecaya untuk 


\section{Jenilan \\ FILSAFATPENDIDIKAN}

menghasilkan data yang dipercaya pula. Dengan bahasa ilmiah lazim dikatakan "Apa yang ada itu dapat dihayati karena dapat diukur"4.

Cara kerja dan hasil filsafat dapat dipergunakan untuk memecahkan masalah hidup dan kehidupan manusia, dimana pendidikan merupakan salah satu dari aspek kehidupan tersebut, karena hanya manusialah yang dapat melaksanakan dan menerima pendidikan. Oleh karena itu pendidikan memerlukan filsafat. Karena masalah-masalah pendidikan tidak hanya menyangkut pelaksanaan pendidikan, yang hanya terbatas pada pengalaman. Dalam pendidikan akan uncul masalah-masalah yang lebih luas, lebih dalam, dan lebih kompleks, yang tidak terbatasi oleh pengalmaan maupun fakta faktual, dan tidak memeungkinkan untuk dijangkau oleh ilmu.

\section{A. Defenisi Filsafat Pendidikan}

Pengertian Filsafat, Berasal dari kata Philos, philore (cinta) dan sophos atau sophia (kebajikan, kebaikan, kebenaran). Ilmu yang mempelajari hakikatsegala sesuatu, Manusia, Alam dan Tuhan.

Berfilsafat berarti berpikir reflektif untuk memperoleh jawaban dari pertanyaan mendasar (radikal) dan universal. Jawaban tersebut disusun secara sistematis, diuji secara kritis dan terbuka untuk memperoleh kebenaran yang sesungguhnya (hakiki). Jawaban terhadap persoalan biasanya tidak pernah selesai, tidak pernah sempurna.

Istilah pendidikan berasal dari kata "didik", dengan memberinya awalan "pe" dan akhiran "kan", mengandung arti "perbuatan" (hal, cara dan sebagainya). Istilah pendidikan ini awalnya berasal dari bahasa Yuanani, yaitu "paedagogie", yang berarti bimbingan yang diberikan kepada anak. Istilah ini kemudian diterjemahkan ke dalam bahasa Inggris dengan "education" yang berarti pengembangan atau bimbingan. Dalam bahasa arab istilah ini sering diterjemahkan dengan “Tarbiyah" yang berarti pendidikan. ${ }^{5}$

Imam Bernadib mendefenisikan filsafat pendidikan sebagai ilmu pendidikan yang bersendikan filsafat, atau filsafat yang diterapkan dalam usaha pemikiran dan pemecahan masalah pendidikan. ${ }^{6}$

Dari defenisi diatas dapat dijelaskan bahwa Filsafat pendidikan adalah cabang filsafat yang mempelajari hakekat pendidikan Filsafat pendidikan memandang kegiatan pendidikan sebagai objek yang perlu dikaji. Ada banyak 
defisini mengenai filsafat pendidikan pada tetapi akhirnya semua berpendapat dan mengajukan soal kaidah-kaidah berpikir filsafat dalam rangka menyelesaikan masalah-masalah yang ada dalam bidang pendidikan. Upaya ini kemudian menghasilan teori dan metode pendidikan untuk menentukan gerak semua aktivitas pendidikan.

Cabang-cabang filsafat yang utama adalah sebagai berikut :

1. Metafisika (ontologi). Metafisika adalah cabang filsafat yang mempelajari hakekat realitas terdalam dari segala sesuatu, baik yang bersifat fisik maupun yang bersifat non fisik.

2. Epistemologi adalah cabang filsafat yang melakukan penelaahan tentang hakekat pengetahuan manusia. Secara khusus, dalam. epistemologi dilakukan kajian-kajian yang mendalam tentang hakekat terjadinya perbuatan mengetahui, sumber pengetahuan, tingkat-tingkat pengetahuan, metode untuk memperoleh pengetahuan, kesahihan pengetahuan, dan kebenaran pengetahuan.

3. Aksiologi adalah cabang filsafat yang mempelajari hakekat nilai. Berdasar pada pokok penekanannya, aksiologi dapat dibagi menjadi etika (filsafat tentang baik buruk perilaku manusia) atau filsafat moral dan estetika atau filsafat keindahan. ${ }^{7}$

\section{B. Fungsi Filsafat dalam Ilmu Pendidikan}

Hubungan antar filsafat dengan pendidikan adalah, filsafat menelaah suatu realitas dengan luas dan menyeluruh, sesuai dengan karateristik filsafay yang radikal, sistematis, dan menyeluruh. Konsep tentang dunia dan tujuan hidup manusia yang merupakan hasil dari studi filsafat, akan menjadi landasan dalam menyusun tujuan pendidikan. Nantinya bangun sistem pendidikan dan praktek pendidikan akan dilaksanaka berorientasi kepada tujuan pendidikan.

hubungan antar filsafat dengan filsafat pendidikan: bahwa filsafat tidak hanya melahirkan ilmu atau pengetahuan baru, melainkan juga melahirkan filsafat pendidikan. Bahkan Jhon Dewey berpendapat bahwa filsafat adalah teori umum pendidikan. Filsafat pendidikan haruslah minimal dapat menjawab pertanyaanpertanyaan mendasar dalam pendidikan. ${ }^{8}$

Filsafat bukanlah hasil dari riset atau eksperimen. Benar atau salahnya tidak mungkin diuji dengan fakta. Filsafat adalah hasil pemikiran. Maka pemikiran pula yang akan menerima atau menolak ${ }^{9}$ 
Keterangan ini mengisyaratkan bahwa filsafat adalah hasil pemikiran yang tentunya dalam proses peningkatan ilmu terdapat klasifikasi, yang pro dan kontra. Pendapat yang mengatakan bahwa filsafat itu adalah ilmu, sedangkan pendapat lain mengatakan bahwa filsafat itu tidak terkait dengan ilmu. ${ }^{10}$

Walaupun antara kebenaran yang disajikan oleh agama mungkin serupa dengan kebenaran yang dicapai oleh filsafat, tetapi tetap ada agama tidak bisa disamakan dengan filsafat. Perbedaan ini disebabkan cara yang berbeda. Di satu pihak agama ber-alat-kan kepercayaan, di lain pihak filsafat berdasarkan penelitian yang menggunakan potensi manusiawi, dan meyakininya sebagai satu satunya alat ukur kebenaran, yaitu akal manusia11, namun demikian tidak mutlak filsafat tidak bisa mengkaji agama untuk menemukan kebanaran-Nya.

Menyikapi masalah kebenaran dalam filsafat dan kebanaran Agama pada umumnya dimaknai di satu sisi agama ber-alat-kan kepercayaan, di lain pihak filsafat berdasarkan penelitian yang menggunakan potensi manusiawi, jika kebenaran yang dibicarakan dengan mempergunakan alat yang sama seperti akal manusia dan terdapat perbedaan yang gambarannya tidak bisa dipertemukan, pada dasarnya hal yang kita cari dapat dikatakan bukan kebenaran. Karena namanya kebenaran walaupun bagaimana wujudnya tetap mengandung makna (kebenaran). Dalam membicarakan kebanaran pastilah wujudnya akan nampak perbedaan dengan bukan kebenaran.

Kebenaran yang diwujudkan ajaran Agama dan hubungannya dengan kebenaran Filsafat sukar untuk dipisahkan, jika hal kebenaran yang kita fikirkan betul-betul kebenaran, karena kebenaran wujudnya sama, tidak berobah dan bahkan sangat menyolok perbedaannya dengan yang namanya bukan kebenaran. Arti dari perbedaan antara kebenaran dan bukan kebenaran ibarat siang dan malam. Kecuali jika diakali atau diserupakan, sehingga dia seakan menampakkan suatu kebenaran, hal ini bisa terjadi jika pelakunya tidak dibarengi dengan iman. Peranan iman-lah yang dapat mengantar suatu pesan untuk dipikirkan lebih jauh dan menghasilkan suatu kebenaran yang bermanfaat dalam bidang filsafat pendidikan.

\section{Kesimpulan}

Pengetahuan yang merupakan produk kegiatan berpikir merupakan tolak ukur pencerahan peradaban dimana 
manusia menemukan dirinya dan menghayati hidup dengan lebih sempurna. Berbagai peralatan dikembangkan manusia untuk meningktkan kualitas hidupnya dengan menerapkan pengetahuan yang diperolehnya. Proses penemuan dan penerapan itulah yang menghasilan kapak dan batu zaman dulu sampai komputer zaman ini. Manusia tidak terlepas dari jangkauan pikirannya yang mencirikan hakekat manusia dan berpikirlan dia menjadi manusia, dan selanjutnya Ilmu pengetahuan berkembang dari rasa ingin tahu, yang merupakan ciri khas manusia.

Ilmu pengetahuan merupakan upaya khusus manusia untuk menyingkapkan realitas, supaya memungkinkan manusia berkomunikasi satu sama lain, membangun dialog dengan mengakui yang lain, dan meningkatkan harkat kemanusiaannya. Oleh karenanya harkat kemanusiaan dapat terangkat jika mengkaji aspek-aspek yang bersifat ke-Ilahi-an, artinya tidak menyepelekan fakta agama atau sejarah para Nabi, oleh karenanya dalam mengkaji fakta Nabi Musa as., dan diterjemahkan oleh bangsa Barat khusunya Amerika Serikat yang notabenenya keturunan Yahudi. Dalam mengimplementasikan sejarah ini dengan wujud sebenarnya, dan mempergunakan metode Nabi Musa dalam membelah gunung, maka wujud nyata dari peristiwa agama dapat memberikan manfaat bagi manusia untuk kemanusiaannya.

\section{Referensi}

1 . Jujun S. Suriasumantri, IImu dalam Perspektif, 2001,(Cet.XV, Jakarta: Yayasan Obor Indonesia), h. 1

2 . Dr. Anton Bakker dan Drs. Achmad Charris Zubair, Metodologi Penelitian Filsafat, 1990, ( Cet: I, Yogyakarta: Kanisius), h. 12-13

3 . H.M. Arifin, Filsafat Pendidikan Islam, 1996, (Jakarta: Bumi Aksara), h. 4

4. Imam Barnadib, Filsafat Pendidikan

Sistem dan Metode, 1987 (Yogyakarta: Andi Offset), h. 13

5 . Ramayulis, Ilmu Pendidikan Islam, 2002, (Jakarta: Kalam Mulia), hal.1.

6 . Iamam Bernadib, Filsafat Pendidikan, 1994, (Yoyakarta: Andi Ofseet) hal. 7

7 . Op, Cit, Imam Bernadib, hal. 67

8. Liem Tjong Tiat. Fisafat Pendidikan dan Pedagogik, 1968, (Bandung: Jurusan FSP FIP IKIP Bandung)

9. Sidigazalba, Sistematika Filsafat "pengantar kepada dunia filsafat", 1992, (Jakarta: Bulan Bintang), h. 50

10. Ibid, hal. 53

11. Dr. Uhaya S. Praja, Aliran Aliran Filsafat dan Etika, (suatu pengantar), 1997 (Bandung: Yayasan Piara), h. 10 